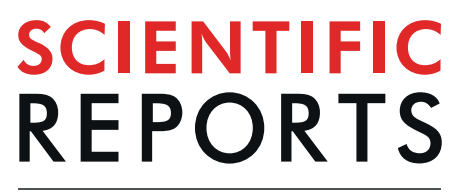

natureresearch

\title{
OPEN First fossil frog from Antarctica: implications for Eocene high latitude climate conditions and Gondwanan cosmopolitanism of Australobatrachia
}

\begin{abstract}
Thomas Mörs ${ }^{1,2 *}$, Marcelo Reguero ${ }^{3}$ \& Davit Vasilyan ${ }^{4,5}$
Cenozoic ectothermic continental tetrapods (amphibians and reptiles) have not been documented previously from Antarctica, in contrast to all other continents. Here we report a fossil ilium and an ornamented skull bone that can be attributed to the Recent, South American, anuran family Calyptocephalellidae or helmeted frogs, representing the first modern amphibian found in Antarctica. The two bone fragments were recovered in Eocene, approximately 40 million years old, sediments on Seymour Island, Antarctic Peninsula. The record of hyperossified calyptocephalellid frogs outside South America supports Gondwanan cosmopolitanism of the anuran clade Australobatrachia. Our results demonstrate that Eocene freshwater ecosystems in Antarctica provided habitats favourable for ectothermic vertebrates (with mean annual precipitation $\geq 900 \mathrm{~mm}$, coldest month mean temperature $\geq 3.75^{\circ} \mathrm{C}$, and warmest month mean temperature $\geq 13.79^{\circ} \mathrm{C}$ ), at a time when there were at least ephemeral ice sheets existing on the highlands within the interior of the continent.
\end{abstract}

Consistent with the geological evidence, it has been hypothesized that the formation of Antarctic ice sheets predates the final break-up of Gondwana, the opening of the Drake Passage and the thermal isolation of the continent ${ }^{1-3}$. This is reflected by a low diversity of terrestrial mammals on the Antarctic Peninsula during the middle to late Eocene with only two species of large mammals and ten species of small mammals ${ }^{4-6}$ which sharply contrasts with the highly diverse marine fish fauna indicating temperate conditions in the Weddell $\mathrm{Sea}^{7,8}$. However, no Cenozoic ectothermic continental vertebrates (freshwater fishes, amphibians and reptiles) have been known from Antarctica so far. Here we report the discovery of a fossil ilium from Seymour Island, Antarctic Peninsula (Fig. 1a,b) which can be assigned to the lissamphibian order Anura, and a fragment of a sculptured skull bone that most probably derived from a hyperossified anuran. We assign the specimens to the South American genus Calyptocephalella. Calyptocephalellids, or helmeted frogs, are widely known from Patagonia since the Late Cretaceous 9 . They became extinct in Argentine Patagonia during the Miocene, probably related to a decrease of humidity caused by the rise of the Andes, since the family survived to the present day in a temperate but humid refuge in the central Chilean Andes ${ }^{10}$.

The material described here derives from estuarine to marginal-marine deposits of the Eocene La Meseta Formation which were deposited in the James Ross Basin, a back-arc basin east of the Antarctic Peninsula, and which are widely exposed on Seymour Island ${ }^{11,12}$ (Fig. 1b,c). The fossil locality IAA 2/95, also known as 'Marsupial Site' is a few $\mathrm{m}^{2}$ wide lens of poorly consolidated, shelly conglomerate ${ }^{8,13}$. It is situated in the central portion of the Cucullaea I Allomember, within unit Telm 5 on the northwestern slope of the mesa (Fig. 1c,d), and informally referred to as the 'Natica horizon's,13. It has produced shark, ray and skate teeth, remains of marine bony fishes, as well as teeth of terrestrial mammals, worm (clitellate) cocoons, and seeds of water lilies ${ }^{8,12-22}$. Based on dinocyst occurrences, the age of this deposit is considered to be about $40 \mathrm{Ma}$ (Bartonian, Eocene) $)^{23,24}$.

\footnotetext{
${ }^{1}$ Department of Palaeobiology, Swedish Museum of Natural History, P.O. Box 50007, SE-104 05, Stockholm, Sweden. ${ }^{2}$ Bolin Centre for Climate Research, Stockholm University, Stockholm, Sweden. ${ }^{3}$ Instituto Antártico Argentino, Campus Miguelete, 25 de Mayo 1151, $3^{\circ}$ piso B1650HMK, San Martín, Buenos Aires, Argentina. ${ }^{4}$ JURASSICA Museum, Route de Fontenais 21, 2900, Porrentruy, Switzerland. ${ }^{5}$ Department of Geosciences, University of Fribourg, Chemin du musée 6, 1700, Fribourg, Switzerland. *email: thomas.moers@nrm.se
} 


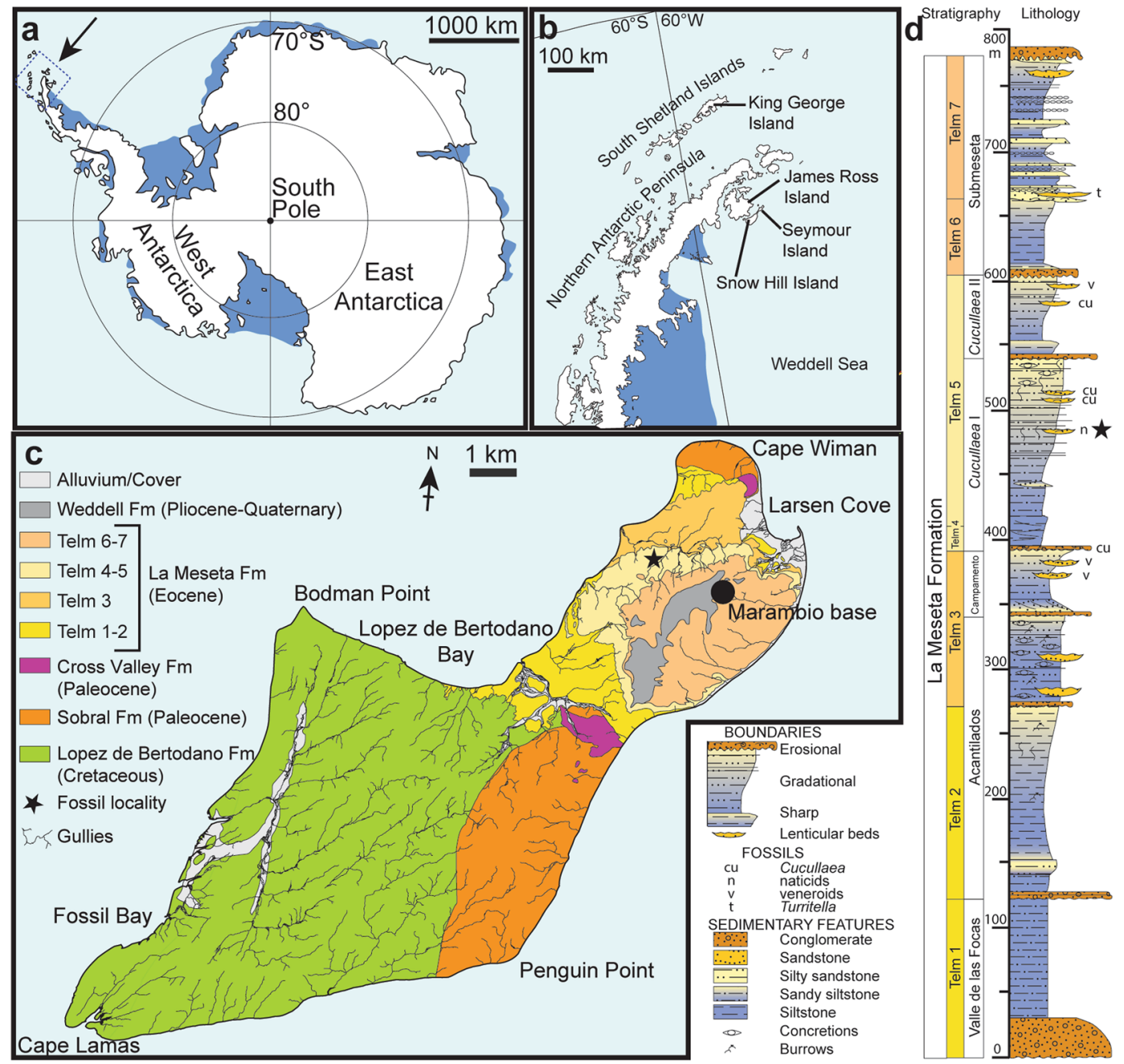

Figure 1. Maps and stratigraphic column of the studied area and succession. (a) Map of Antarctica showing the location of the study area. (b) Map of the northern Antarctic Peninsula showing the location of Seymour Island. (c) Geological sketch map of Seymour Island, showing the position of the fossil locality (asterisk). (d) Stratigraphic column of the La Meseta Formation on Seymour Island (from ${ }^{11}$ ) showing the position of the fossil locality (asterisk). Redrawn from ${ }^{13}$.

The fossil frog remains were collected during three joint Argentinian-Swedish expeditions to Seymour Island in the austral summers 2011-13. The bone fragments were concentrated from dry-sieved sediment samples as described by ${ }^{8,12,20}$ and sorted by using a Leica MZ6 stereomicroscope. The material is housed in the palaeozoological collections of the Swedish Museum of Natural History, Stockholm, with the inventory numbers NRM-PZ B281 and B282.

\section{Results}

Systematic palaeontology. Anura Fischer von Waldheim, $1813^{25}$

Neobatrachia Reig, $1958^{26}$

Australobatrachia Frost et al., $2006^{27}$

Calyptocephalellidae Reig, $1960^{28}$

Calyptocephalella Strand, $1928^{29}$

Calyptocephalella sp.

Figures 2 and 3

Referred specimens. Swedish Museum of Natural History NRM-PZ B282, right ilium (Fig. 2), NRM-PZ B281, skull bone (Fig. 3).

Locality, horizon and age. IAA 2/95, Marsupial site, Seymour Island, Antarctic Peninsula (64 ${ }^{\circ} 13^{\prime} 58^{\prime \prime}$ S; $56^{\circ} 39^{\prime} 06^{\prime \prime} \mathrm{W}$ ). 'Natica horizon' within the Cucullaea I Allomember (Telm 5) of the La Meseta Formation, Bartonian (40 Ma), Eocene ${ }^{23,24}$ (Fig. 1). 

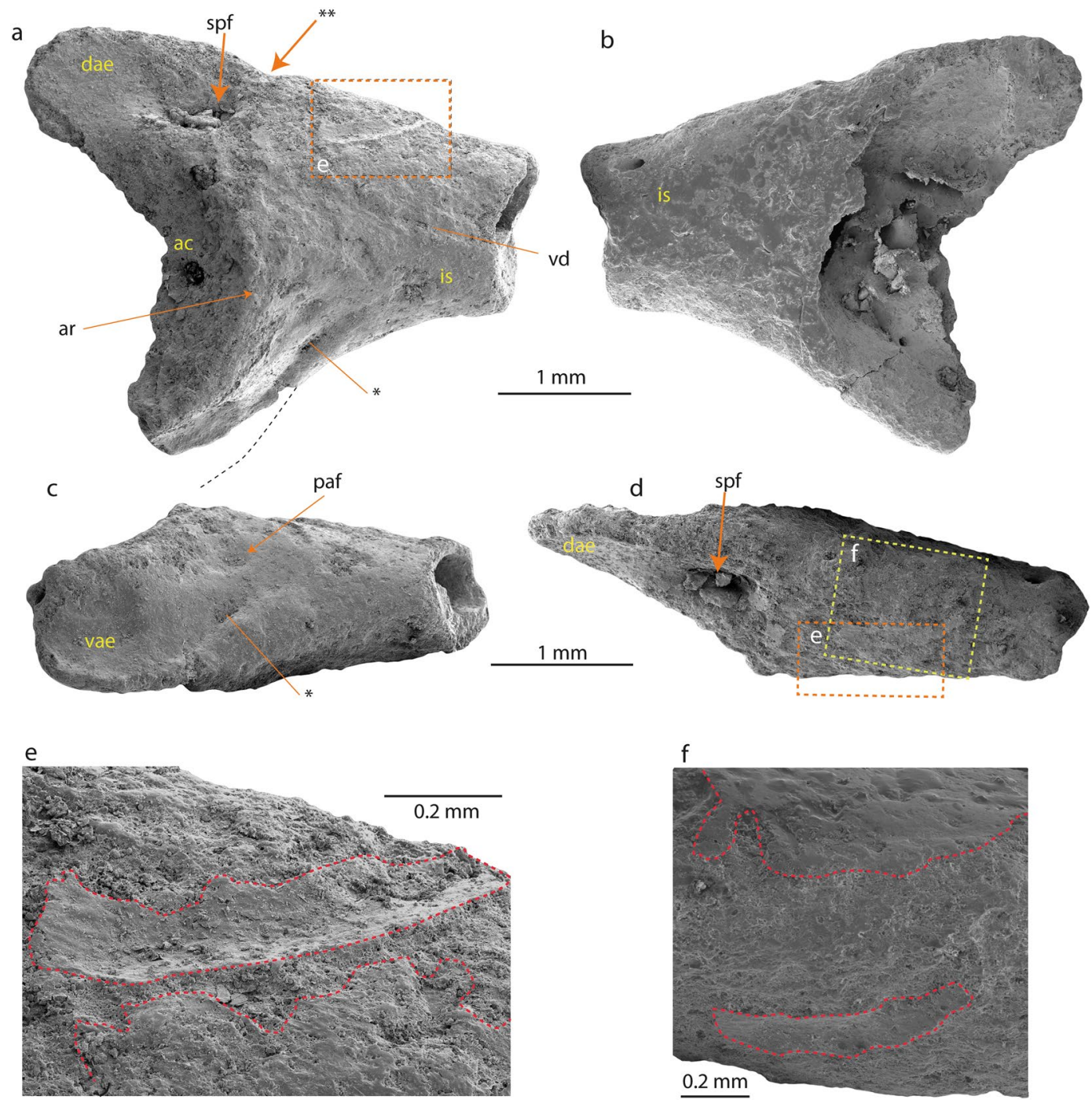

Figure 2. Ilium (NRM-PZ B282) of Calyptocephalella sp. from Seymour Island, Antarctica. Ilium in lateral (a), medial (b), ventral (c) and dorsal (d) views. Magnified region of the dorsal protuberance in lateral (e - dashed rectangle in orange color) and dorsal (f - dashed rectangle in yellow color) view. The dashed line in black on (a) indicates the probable outline of the posterior extension of the ventral acetabular expansion. The asterisk (*) on $(\mathbf{a}, \mathbf{c})$ indicates the shallow and broad depression of the ventral acetabular expansion. The double asterisk $(* *)$ indicates the notch caudally from the dorsal protuberance. The dashed red lines on (e,f) outline the intact bone surface. Abbreviations: ac, acetabulum; ar, acetabular rim; dae, dorsal acetabular expansion; is, iliac shaft; paf, preacetabular fossa; spf, supraacetabular fossa; vae, ventral acetabular expansion; vd, ventral depression.

Measurements. The preserved part of the ilium measures $3.9 \mathrm{~mm}$ in length, the distance from the tip of the dorsal acetabular expansion to the (preserved) tip of the ventral acetabular expansion measures $3.3 \mathrm{~mm}$, the highest height of the acetabular fossa equals $2.5 \mathrm{~mm}$. The skull bone measures $2.7 \mathrm{~mm}$ at its both broadest and longest parts.

Ilium. The fragmentary right ilium (NRM-PZ B282) lacks the caudal portion of the acetabulum and most of the iliac shaft. The dorsal acetabular expansion has a smooth lateral surface and is higher than the preserved part of the ventral acetabular expansion (Fig. 2a). A large and deep supraacetabular fossa is present at its base (Fig. 2a,d). The preserved portion of the acetabulum is concave and its shape allows concluding a (semi-)circular outline. The acetabular rim is most prominent at its anterior part (Fig. 2a,c). The barely-developed ventral acetabular expansion projects ventrally. The posterior-most portion of the ventral acetabular expansion is broken off. However, the anterior portion of the ventral acetabular expansion is higher than the preserved posterior portion. In ventral view (Fig. 2a,c), the lateral surface of the ventral acetabular expansion is convex. The ventral acetabular expansion possesses a shallow and broad depression. In the preacetabular zone, a small and shallow preacetabular fossa is present (Fig. 2c). The preserved portion of the iliac shaft is damaged and precludes a confident statement whether the dorsal protuberance is present or absent. A narrow and shallow longitudinal groove is observable in the lateral surface of the iliac shaft, which probably corresponds to the posterior extension of the ventral 


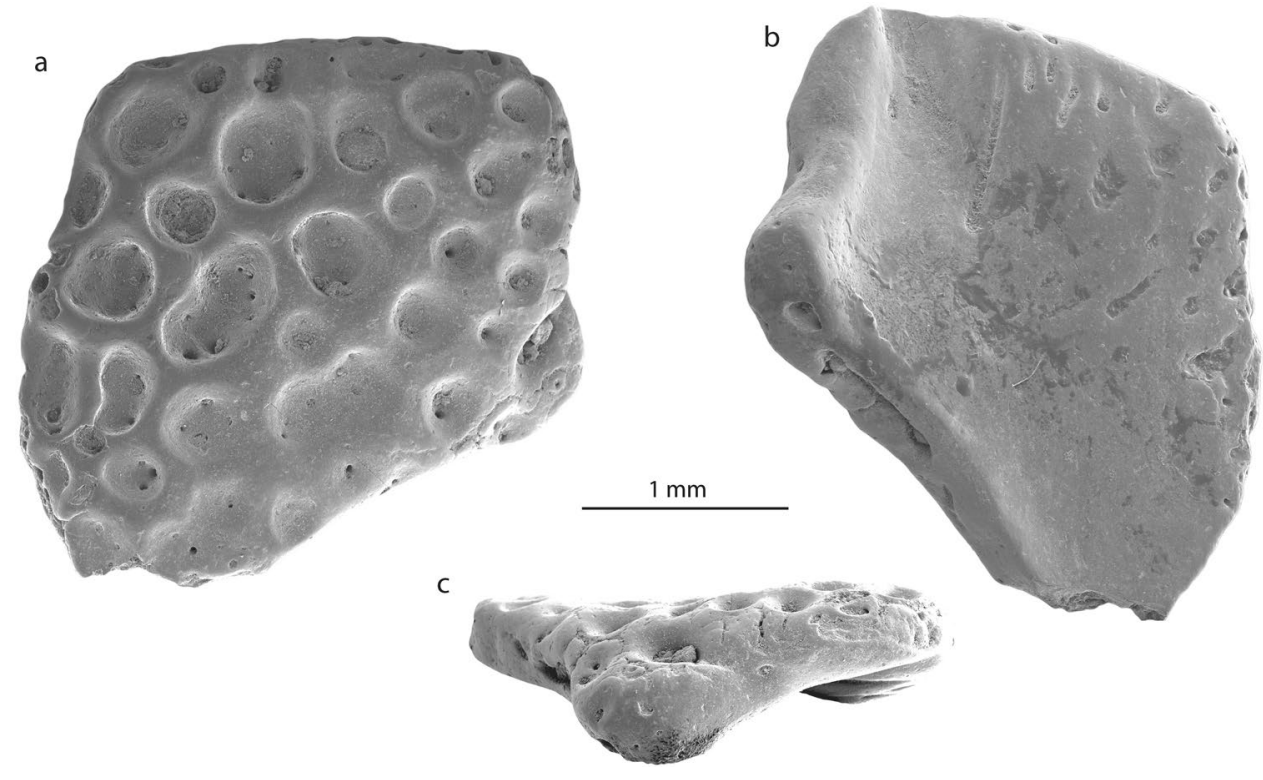

Figure 3. Skull bone fragment (NRM-PZ B281) of Calyptocephalella sp. from Seymour Island, Antarctica in dorsal (a), ventral (b) and lateral (c) views.

\begin{tabular}{|l|l|l|l|l|l|l|}
\hline species & locality & coll nr. & SVL (in mm) & HT (in mm) & RHS (in \%) & Reference \\
\hline C. pichileufensis & Río Pichileufú locality & BAR 85b & 107 & 6 & 5.6 & $48:$ Figs. 2 and 4 \\
\hline C. gayi & unknown & M13105/cas:sua:10082* & 54.7 & 2.9 & 5.3 & 65 , see Fig. S3 \\
\hline range & & & $5.3-5.6$ & \\
\hline mean \pm SD & \multicolumn{3}{l}{} & & $5.45 \pm 0.21$ & \\
\hline C. sp. & IAA 2/95, Marsupial site & NRM-PZ B282 & $\mathbf{3 8 . 4} \pm \mathbf{3 . 8}$ & $\mathbf{2 . 1}$ & & Present work \\
\hline
\end{tabular}

Table 1. Measurements of the snout-vent length (SVL) and height of the transition from the iliac shaft and ilial body (HT) of some Calyptocephalella spp. and Antarctic ilia (Fig. S3), with the value of the ratio between HT and SVL (RHS $=$ HT/SVL* $100 \%$ ) with the value of the standard deviation (SD). The reconstructed value of the snout-vent length of the studied ilium is highlighted in bold.

depression $\left(\right.$ sensu $\left.^{10}\right)$ (Fig. 2a). However, intact parts of bone surface are preserved slightly ventral to the dorsal margin on both lateral and medial surfaces (Fig. 2e,f). The one on the lateral surface is a curved shallow groove and runs posteroventrally (Fig. 2e). This feature anteroventrally demarcates the slightly elevated roughened scar interpreted above as the dorsal protuberance. The area between the dorsal acetabular expansion and iliac shaft is slightly projected dorsally. This area corresponds to the position of the dorsal protuberance. In fact, no clear evidence of a dorsal protuberance can be found on the ilium, only a slightly roughened area with minimal elevation that corresponds to the dorsal protuberance and the scar for the insertion of the musculus gluteus magnus can be observed. At the caudal side of the dorsal protuberance, a distinct notch is visible (Fig. 2a) which we consider as a further evidence of our interpretation. The area corresponding to the dorsal protuberance is located anteriorly to the anterior margin of the acetabular rim. Medially, the entire surface opposing the acetabulum is lost and the area preserved more anteriorly is slightly convex medially and smooth. Anteriorly and dorsally, just adjacent to the anterior end of the dorsal protuberance a foramen is present (Fig. 2b).

The fragmentary right ilium can be referred to an anuran based on the following characters ${ }^{30}$ (the numbers before the characters correspond to the feature numbers of Appendix 1 in Gardner et al. ${ }^{30}$ ): 7 . (semi-) circular acetabulum; 9. acetabulum with distinct margins; 10. acetabular surface concave; 13 . at least dorsal acetabular expansion is strongly divergent; 18 . the dorsal protuberance present. Thus, the ilium derives from a small-sized frog $(3.8 \pm 0.4 \mathrm{~cm}$ snout-vent length, see methods, Table 1$)$. The specimen is partly eroded and rather poorly preserved; however, it can be compared with all South American and Australian frog families (Figs. 4, S1 and S2, Table S1). The families Ranidae, Bufonidae and Hylidae have not been illustrated in the present work, since their morphology is well known ${ }^{31}$ (Table S1). The comparison has been done at family level, since the ilia display diagnostic features characteristic for identification of the family (dimensions of the dorsal and ventral acetabular expansions; location of the dorsal protuberance relative to the anterior margin of the acetabular rim etc. ${ }^{32,33}$ ). The studied ilium (NRM-PZ B282) differs in: (1) Reduced anterior portion of the dorsal acetabular expansion from nearly all South American and Australian frog families and the genus Telmatobufo, which have moderately or strongly developed anterior portion of the dorsal acetabular expansion. Only the genus Calyptocephalella (Fig. 4c,e), the families Ranidae ${ }^{31}$, Pipidae (Fig. S1a), Rhinodermatidae (Fig. S1j), and Leptodactylidae (Fig. S2b) have similar state/morphology of this character. (2) Dorsal protuberance located either at the level of or anteriorly 


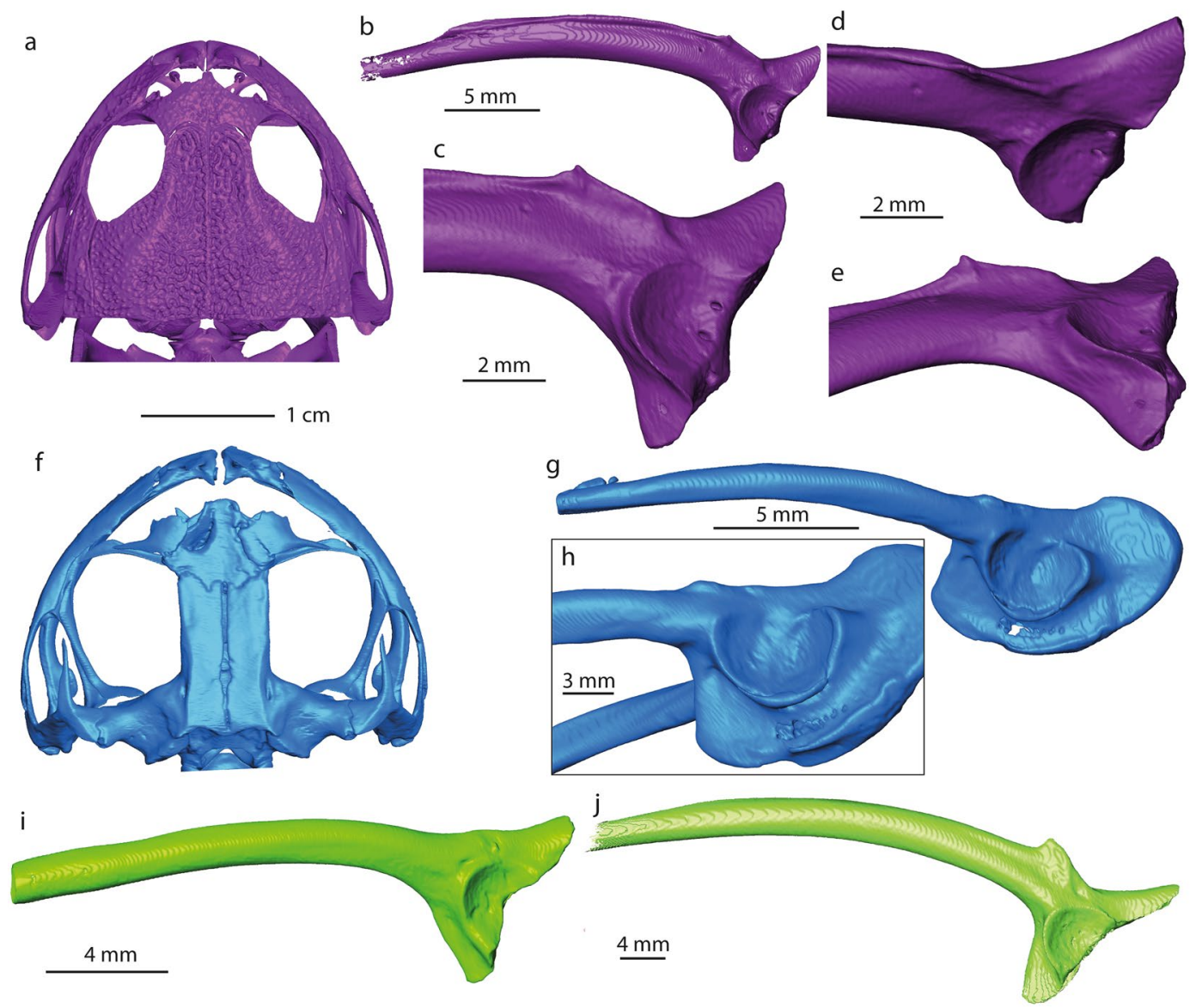

Figure 4. 3D models of some skeletal elements of Australobatrachia. (a,f) skull and (b-e,g-j) ilia of Calyptocephalella gayi (a-e); Telmatobufo venustus (f-h); Myobatrachus gouldii (i); Limnodynastes convexiusculus (j). Collection numbers of each specimen are listed in Table S1.

from the anterior margin of the acetabular rim from nearly all families, besides Brachycephalidae (Fig. S1a), Rhinodermatidae (Fig. S1j), Telmatobiidae (Fig. S1k), Hyloididae (Fig. S1m), Leptodactylidae (Fig. S2b) and the genera Calyptocephalella (Fig. 4b-e) and Telmatobufo (Fig. 4g,h). (3) Developed dorsal acetabular expansion from the families Ranidae ${ }^{31}$, Hylidae ${ }^{31}$, Bufonidae ${ }^{31}$, Myobatrachidae (Fig. 4i), Pipidae (Fig. S1i), Microhylidae (Fig. S1b), Telmatobiidae (Fig. S1k), Leptodactylidae (Fig. S2b), Allophrynidae (Fig. S2c), Centrolenidae (Fig. S2d) and the genus Telmatobufo (Fig. 4g,h). Other families have moderately or well-developed dorsal acetabular expansion, however, due to incomplete preservation of the Antarctic frog remain any further comparison is impossible. (4) Weakly developed dorsal protuberance and lack of dorsal tubercle from nearly all families (e.g. Limnodynastidae, Fig. 4j), besides Calyptocephalellidae (Fig. 4b-e,g,h), Myobatrachidae (Fig. 4i), Craugastoridae (Fig. S1e), and Dendrabatidae (Fig. S2e).

Among the compared forms, only the South American endemic genus Calyptocephalella resembles all mentioned four characters. In addition to this, a shallow and broad depression on the anterior portion of the ventral acetabular expansion is a unique character observable on our ilium (NRM-PZ B282) and Recent Calyptocephalella gayi (Fig. 4). Further, the fossil ilium displays a ventral depression on its lateral surface anteriorly to the acetabulum (Fig. 2c), a comparable structure can be observed also in the fossil species Calyptocephalella canqueli ${ }^{9}$ but not in the Recent species C. gayi (Fig. 4).

Skull element. The second bone fragment (NRM-PZ B281) is flat and slightly curved. Both sides of the bone have different structures. One surface is covered by small to large circular or reniform in outline, rather deep pits, which sink in the planar surface of the bone (Fig. 3a). The diameters of pits vary from $0.1-0.7 \mathrm{~mm}$ and some of them are punctured by foramina. The opposite surface of the bone is in general smooth, slightly deepened and is pierced with some foramina, some of which are preceded by a groove (Fig. 3b). One side of the fragment preserves an unbroken margin of the original bone with a distinct process that is bent and that gives the bone a curved shape (Fig. 3c). The ornamented surface of the bone projects slightly over this process. Comparable ornamentation, build of pits of different size, is found on the dorsal surfaces of different cranial and postcranial bones of amphibians and reptiles ${ }^{34,35}$. Among them, the following groups can be excluded from consideration: (1) Albanerpetontidae (Allocaudata); albanerpetontids are a primary Laurasian lissamphibian group with a single occurrence in Northern Africa. So far no evidence of a Gondwanan radiation of albanerpetontids exists ${ }^{36}$. In addition to this, all their ornamented bones (e.g. frontal, premaxillae) ${ }^{37}$ do not resemble the bone described 
here. (2) Caudata; salamanders are also considered as a Laurasian group, with a number of occurrences in Africa which need critical revision ${ }^{38}$. In salamanders, ornamented bones are found both among skull bones and on vertebrae (on plates located on the tip of the neural arch) ${ }^{39}$. Bone ornamentation here (e.g. Tylototriton, Chelotriton, Echinotriton ${ }^{39,40}$ ) is represented by a network of pits, ridges and pointy spines that do not resemble the bone described here. (3) Crocodylia; in crocodyliforms, comparable patterns of ornamentation with well-developed pits appear only with growth during later ontogenetic stages ${ }^{41-43}$. On one hand, the bone dimensions indicate a small-sized animal (corresponding to a juvenile crocodilian without such developed ornamentation). On the other hand, crocodylian osteoderms are flat without any processes, unlike the studied bone. (4) Testudines; shell plates of several turtles, such as Trionyx, Allaeochelys etc. ${ }^{35}$, are also covered by ornamentation. The ornamentation is characterized by larger and closely arranged pits, which are not always clearly delimited from each other (see Scheyer ${ }^{35}$ : Fig. 1a). (5) Lacertilia; lizards also have skull bones and osteoderms covered with ornamentation patterns ${ }^{44}$. They all are characterized by a network of spines, grooves, ridges ${ }^{45}$ and protuberances ${ }^{46}$, which differs from the morphology on NRM-PZ B281.

The ornamentation pattern found in NRM-PZ B281 is comparable to that of some frog genera, i.e. Thaumastosaurus $^{47}$, Beelzebufo ${ }^{48}$, Calyptocephalella ${ }^{9}$ and Baurubatrachus ${ }^{49}$, but only the last three genera are Gondwanan forms and, thus, considered for comparison herein. Beelzebufo is a very large form and the ornamentation pattern is present both on skull bones and on vertebrae ${ }^{50}$. Calyptocephalella ${ }^{9}$ and Baurubatrachus ${ }^{49}$ have very similar ornamentation patterns on the surfaces of hyperossified skull bones, comparable to our specimen. A recent phylogenetic analysis ${ }^{49}$ placed the Late Cretaceous Baurubatrachus within both Recent calyptocephalellid genera Calyptocephalella and Telmatobufo. Though Muzzopappa and Báez ${ }^{10}$ mention that both Calyptocephalella and Telmatobufo are characterized by a heavily ossified neurocranium, we can confirm this only for the former genus (Fig. 4a,f). Within Calyptocephalella the ornamentation pattern on skull bones is variable. In C. conquella ${ }^{10}$, it is built either by network of pits in small individuals, or tuberculated ornamentation in adults. In C. $\operatorname{satan}^{9}$ and C. casamayorensis $^{51}$, ornamented skull bones are slightly larger than NRM-PZ B281 but they have a similar pattern built of pits. C. pichifleufensis ${ }^{48}$ is known by larger individuals which show similar ornamentation patterns but with larger pits. In comparison to these species, the Antarctic frog displays an ornamentation most similar to that of C. satan $^{9}$ and C. casamayorensis ${ }^{48}$. Taking into account our comparison, we conclude that the ornamented bone fragment NRM-PZ B281 represents a skull bone (most probably a nasal) of a small-sized Calyptocephalella or Baurubatrachus. Given the presence of a small Calyptocephalella as indicated by the ilium in the same, only few $\mathrm{m}^{2}$ measuring outcrop, it is most likely that specimen NRM-PZ B281 belongs to the same genus. A comparable record of an ilium and ornamented bones referable to the genus Calyptocephalella has been mentioned in Báez ${ }^{52}$.

\section{Discussion}

Among Recent amphibians, the frogs (Anura) have the widest distribution, covering all continents except Antarctica, where the conditions have been uninhabitable for over tens of millions of years. Contrary to all other continents, no traces of any extant amphibian group, all of which belong to the lissamphibian clade, have been documented from Antarctica. This paper presents the first record of a lissamphibian in Antarctica, with Eocene fossils referable to the order Anura, and most likely to the australobatrachian genus Calyptocephalella. The family Calyptocephalellidae belongs to neobatrachian frogs and is exclusively known from South America ${ }^{53,54}$. The five extant species, including the monospecific genus Calyptocephalella with hyperossified skull bones, are restricted to the Chilenean Andes ${ }^{54}$ while most fossil representatives are known from Argentine Patagonia ${ }^{9,48,53}$. Today, Calyptocephalella inhabits lowland areas of central Chile (upper elevation limit $500 \mathrm{~m}$ ) east of the Andes within temperate and humid climates, between latitudes $30-43^{\circ} \mathrm{S}$. It has an aquatic or semiaquatic lifestyle and populates standing or slow flowing water bodies (lakes, ponds, streams) in the Valdivian temperate Nothofagus forests ${ }^{54-56}$.

The oldest fossils referable to Calyptocephalella are known from the Upper Cretaceous of Argentina ${ }^{9,52}$. During the Paleocene-terminal early Miocene, their geographic range was restricted to Patagonia east of the Andes $^{48,51,53,57}$. Not until the late Pleistocene did they appear west of the Andes, where they have their endemic present-day distribution ${ }^{54-57}$.

The clade Australobatrachia comprises Myobatrachoidea (families Myobatrachidae + Limnodynastidae $\mathrm{sensu}^{27}$ ), nowadays distributed in Australia and south of New Guinea, and the family Calyptocephalellidae (Batrachophrynidae sensu ${ }^{27}$ ). Australobatrachia are considered as a stem group of the Hyloidea. The earliest myobatrachoid from Australia is at least as old as early Eocene, based on fragmentary ilia that were referred to the basal extant Lechriodus ${ }^{58}$. The split between Calyptocephalellidae and Myobatrachidae (Calyptocephalellidae + Myobatrachoidea sensu $^{27}$ ) occurred $\sim 100 \mathrm{Ma}$ ( Early-Late Cretaceous boundary $)^{59}$. Considering the distributions of extant Australobatrachia (Fig. 5), the earliest fossil records ${ }^{10}$ and the divergence age (from genetic data) ${ }^{59}$ of both Calyptocephalellidae and Myobatrachoidea lineages, it is clear that Antarctica had played an important palaeobiogeographic role for Australobatrachia and their consequent dispersal. Because the most recent common ancestor of the clade, including Hyloidae and Myobatrachidae + Calyptocephalellidae, occurred in South America, their origin in South America and consequent dispersal from South America to Australia via Antarctica has been suggested ${ }^{59}$. Additionally, this suggests one more case of strong faunistic affinities of the continent with South America and Australia ${ }^{4,6,16,60}$. So far, Antarctica has been considered as a dispersal route, but not as a probable place of origin. The new fossil finds support the hypothesis ${ }^{10}$ that Antarctica may have acted as a center of diversification for australobatrachians.

The Seymour Island frog reported herein is the first vertebrate indicative of freshwater habitats on the Eocene Antarctic Peninsula, following invertebrate and plant evidence ${ }^{12,17}$ (Fig. 6). It is interesting to note that nearly all fossil localities where Calyptocephalella occurs (excepting those, for which fossil plant data are not available) contain evidence of the presence of Nothofagus, including Seymour Island ${ }^{16,60,61}$. The southern extant range of Calyptocephalella occurs sympatrically with the microbiotherian marsupial Dromiciops gliroides (Fig. S4), also known as "Monito del Monte" or "Colocolo Opossum", a small mammal with an arboreal lifestyle and an endemic 


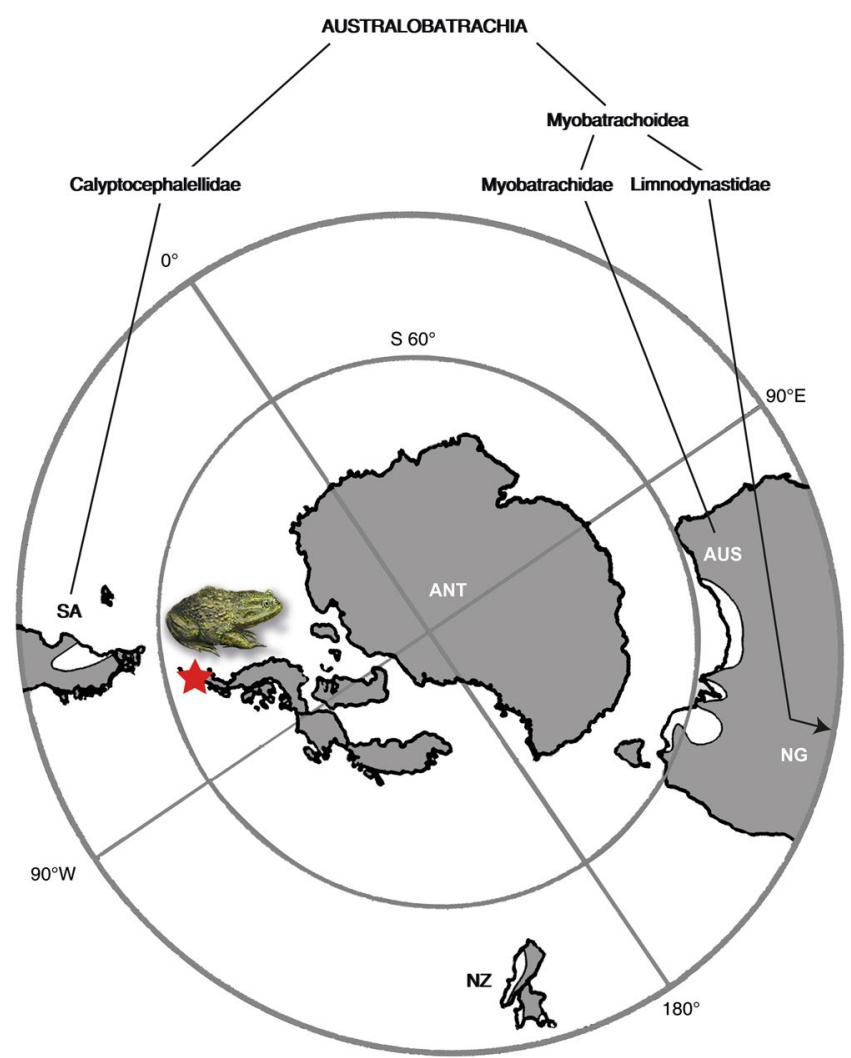

Figure 5. Eocene palaeogeography of the south polar region with a cladogram of australobatrachid frogs showing their occurrences on the southern continents. The grey color indicates the outlines of the continents during the Eocene, the black colored outline the present-day outlines of the continents. Map redrawn from an original generated using ArcGIS 10.17.1 (www.esri.com) software, based on the Satellite base map layer in google Maps (Map data (2019 Google). Abbreviations: ANT, Antarctica; AUS, Australia and Tasmania; NG, New Guinea; NZ, New Zealand; SA, South America. The red star indicates the fossil locality on Seymour Island.

distribution in the dense Valdivian Nothofagus forests of highland Argentina and Chile ${ }^{62}$. The climate of this Nothofagus forest area with the sympatric occurrences of these two endemic animals shows humid and temperate conditions (for the numerical values, see Methods and Table 2, Fig. S4). Dromiciops gliroides is the only extant species of the order Microbiotheria and is considered as the only South American representative of the superorder Australidelphia which otherwise comprises Australian marsupials ${ }^{63}$. From the same small shell-rich lens that produced the frog remains reported herein, the fossil microbiotherian Woodburnodon casei has been described ${ }^{64}$. Hence, we hypothesize that the climatic conditions for the Antarctic Peninsula during the Bartonian (late middle Eocene) should be comparable with the climate found today in the concurrent range of the Calyptocephalella-and Dromiciops-inhabited Nothofagus forests of South America.

The fossil finds of a frog and marsupial from Seymour Island, and their fossil and Recent distributions, represent outstanding examples of the role of global climate change on shifting biogeographic ranges. Despite global cooling and the disappearance of the habitats of these groups over large areas from Antarctica to Patagonia, they maintained their relictual occurrence in the Nothofagus forests of the central Chilean Andes. Thus, the Valdivian Nothofagus forest is a unique environment offering habitats not only for Eocene Antarctic refugees but also provides a modern analogue of the Antarctic climate just prior to the glaciation of the southern continent.

\section{Methods}

Documentation. The studied fossil material has been mounted on aluminum stubs, coated with gold and imaged using a Hitachi S-4300 field emission scanning-electron microscope at the Swedish Museum of Natural History (Stockholm). For the comparison with relevant families (Table S1), the CT data from the website Morphosource ${ }^{65}$ have been used. The visualization and segmentation of the bone material have been performed using the Amira 9.0 software in Porrentruy, Switzerland.

Nomenclature. If not otherwise indicated, the osteological nomenclature of this study follows that of Gómez and Turazzini ${ }^{66}$ for the description of the fossil remains.

Body size estimation. The values of the snout-vent length (SVL) of Calyptocephalella sp. from Antarctica have been reconstructed using photographs of the skeleton of C. pichileufensis ${ }^{48}$ and the 3D model of C. gayi 


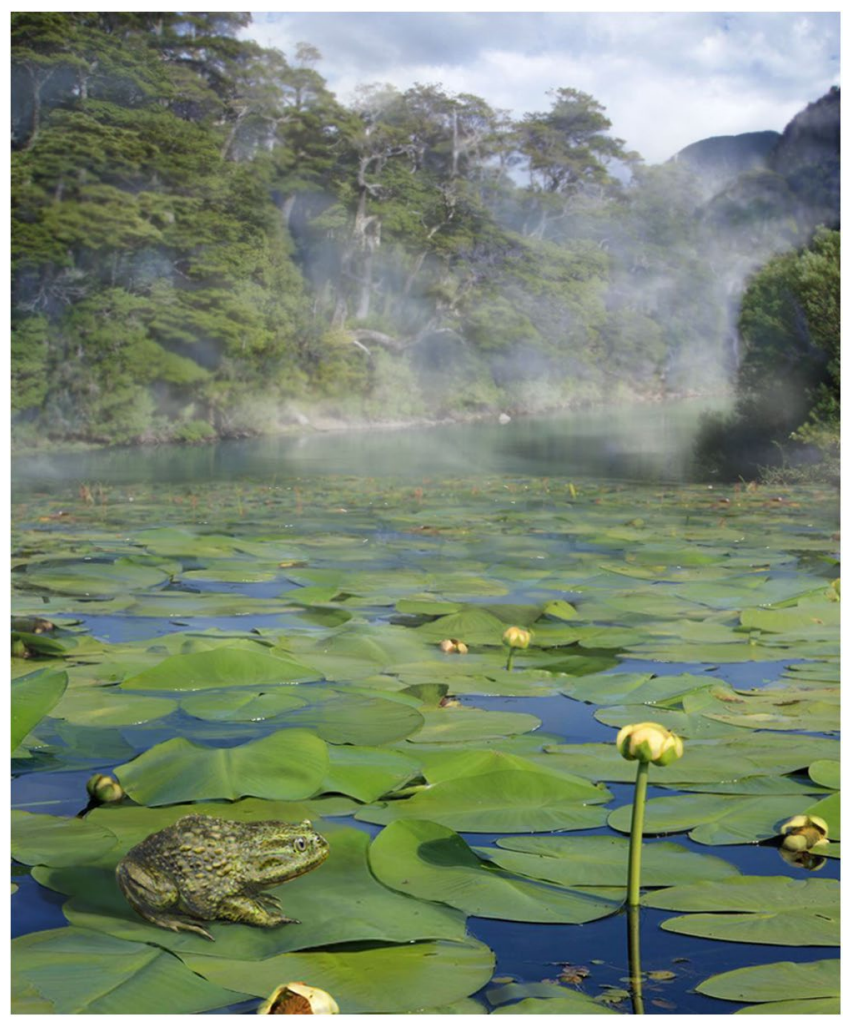

Figure 6. Reconstruction of an Eocene pond in the Nothofagus forest of the Antarctic Peninsula with Calyptocephalella, sitting on a leaf of Notonuphar antarctica which was described from the same locality ${ }^{12}$. Artwork by Pollyanna von Knorring, Swedish Museum of Natural History. Photo credits: Simon Pierre Barrette and José Grau de Puerto Montt, Wikimedia Commons (CC BY-SA 3.0), and Mats Wedin, Swedish Museum of Natural History.

\begin{tabular}{|l|l|l|l|l|l|l|l|l|l|}
\hline $\begin{array}{l}\text { Station } \\
\text { number }\end{array}$ & $\mathbf{1}$ & $\mathbf{2}$ & $\mathbf{3}$ & $\mathbf{4}$ & $\mathbf{5}$ & $\mathbf{6}$ & $\mathbf{7}$ & $\mathbf{8}$ & $\mathbf{9}$ \\
\hline City & Loanco & Nirivilo & Chillan & Antuco & Curacautin & Choshuenco & Huequi & Puerto Montt & Valdivia \\
\hline Elevation $(\mathrm{m})$ & 70 & 220 & 127 & 550 & 541 & 200 & 30 & 100 & 100 \\
\hline MAP $(\mathrm{mm})$ & 877.82 & 919.5 & 998 & 1024.5 & 988.7 & 1903.53 & 1830 & 1610.8 & 1870 \\
\hline MCMT $\left({ }^{\circ} \mathrm{C}\right)$ & 8.74 & 7.9 & 7.69 & 5.27 & 3.75 & 4.51 & 5.04 & 5.57 & 6.9 \\
\hline MWMT $\left({ }^{\circ} \mathrm{C}\right)$ & 18.05 & 18.04 & 18.45 & 17.28 & 15.5 & 15 & 13.79 & 14.7 & 15.5 \\
\hline
\end{tabular}

Table 2. Climatic parameters (MAP, MCMT, MWMT) and the elevation at the climatic stations according to the database of the word bank groups ${ }^{67}$. Abbreviations: MAP $=$ mean annual precipitation, $\mathrm{MCMT}=$ mean coldest month temperature, MWMT = mean warmest month temperature. The location of the climatic stations can be found on Fig. S4.

(Table 1, Fig. S3). The height of the transition (HT) from the iliac shaft and ilial body (Fig. S3) have been used as reference for comparison to reconstruct the body size of NRM-PZ B282. The ratio of the HT to SVL has been used as a reference to calculate the value of the snout-vent lenth of the individual NRM-PZ B282.

Climatic analysis. We analyzed the climatic parameters of selected stations from the area with sympatric occurrence of Dromiciops gliroides and Calyptocephalella gayi (Table 2 and Fig. S4). Since the upper elevation limit for extant Calyptocephalella distribution is $500 \mathrm{~m}$ above sea level, only stations up to this elevation have been considered for climate analysis. This analysis shows a remarkable climatic space with mean annual precipitation $\geq 900 \mathrm{~mm}$, coldest month mean temperature $\geq 3.75^{\circ} \mathrm{C}$, and warmest month mean temperature $\geq$ $13.79^{\circ} \mathrm{C}$ (Table 2). The climatic parameter variations result from both elevation and latitudinal differences, so the temperature increases and the precipitation decreases northwards, whereas an opposite trend is observable at higher altitudes.

Received: 8 November 2019; Accepted: 4 March 2020;

Published online: 23 April 2020 


\section{References}

1. Pekar, S. F., Hucks, A., Fuller, M. \& Li, S. Glacioeustatic changes in the early and middle Eocene (51-42 Ma): Shallow-water stratigraphy from ODP Leg 189 Site 1171 (South Tasman Rise) and deep-sea $\delta 180$ records. Geol. Soc. Am. Bull. 117, 1081-1093 (2005).

2. Miller, K. G., Wright, J. D. \& Browning, J. V. Visions of ice sheets in a greenhouse world. Mar. Geol. 217, 215-231 (2005).

3. Zachos, J., Pagani, M., Sloan, L., Thomas, E. \& Billups, K. Trends, rhythms, and aberrations in global climate 65 Ma to present. Science 292, 686-693 (2001).

4. Woodburne, M. O. \& Zinsmeister, W. J. Fossil land mammal from Antarctica. Science 218, 284-286 (1982).

5. Woodburne, M. O. \& Case, J. A. Dispersal, vicariance, and the Late Cretaceous to Early Tertiary land mammal biogeography from South America to Australia. J. Mamm. Evol. 3, 121-161 (1996).

6. Gelfo, J. N., Mörs, T., Lorente, M., López, G. M. \& Reguero, M. The oldest mammals from Antarctica, early Eocene of the La Meseta Formation, Seymour Island. Palaeontology 58, 101-110 (2015).

7. Kriwet, J., Engelbrecht, A., Mörs, T., Reguero, M. \& Pfaff, C. Ultimate Eocene (Priabonian) Chondrichthyans (Holocephali, Elasmobranchii) of Antarctica. J. Vertebr. Paleontol. 36, e1160911 (2016).

8. Schwarzhans, W., Mörs, T., Engelbrecht, A., Reguero, M. \& Kriwet, J. Before the freeze: Otoliths from the Eocene of Seymour Island, Antarctica, reveal dominance of gadiform fishes (Teleostei). J. Syst. Palaeontol. 15, 147-170 (2017).

9. Agnolin, F. A new Calyptocephalellidae (Anura, Neobatrachia) from the Upper Cretaceous of Patagonia, Argentina, with comments on its systematic position. Stud. Geol. Salamanticensia 48, 129-178 (2012).

10. Muzzopappa, P. \& Báez, A. M. Systematic status of the mid-Tertiary neobatrachian frog Calyptocephalella canqueli from Patagonia (Argentina), with comments on the evolution of the genus. Ameghiniana 46, 113-125 (2009).

11. Reguero, M., Goin, F., Acosta Hospitaleche, C., Dutra, T. \& Marenssi, S. Late Cretaceous/Paleogene West Antarctica Terrestrial Biota and its Intercontinental Affinities 55-110 (Springer, 2013).

12. Friis, E. M., Iglesias, A., Reguero, M. A. \& Mörs, T. Notonuphar antarctica, an extinct water lily (Nymphaeales) from the Eocene of Antarctica. Plant Syst. Evol. 181, 969-980 (2017).

13. McLoughlin, S., Bomfleur, B., Mörs, T. \& Reguero, M. Fossil clitellate annelid cocoons and their microbiological inclusions from the Eocene of Seymour Island, Antarctica. Palaeontol. Electron. 19, 1-27 (2016).

14. Goin, F. J., Case, J. A., Woodburne, M. O., Vizcaíno, S. F. \& Reguero, M. A. New Discoveries of “Opposum-Like” Marsupials from Antarctica (Seymour Island, Medial Eocene). J. Mamm. Evol. 6, 335-365 (1999).

15. Bond, M., Reguero, M.A., Vizcaíno, S.F. \& Marenssi, S. Cretaceous-Tertiary high-latitude palaeoenvironments: James Ross Basin, Antarctica, (ed. Francis, J. E., Pirrie, D. \& Crame, J. A.) 163-176 (Geological Society, 2006).

16. Chornogubsky, L., Goin, F. J. \& Reguero, M. A reassessment of Antarctic polydolopid marsupials (Middle Eocene, La Meseta Formation). Antarct. Sci. 21, 285-297 (2009).

17. Bomfleur, B., Mörs, T., Ferraguti, M., Reguero, M. A. \& McLoughlin, S. Fossilized spermatozoa preserved in a 50-Myr-old annelid cocoon from Antarctica. Biol. Letters 11, 20150431, https://doi.org/10.1098/rsbl.2015.0431 (2015).

18. Engelbrecht, A., Mörs, T., Reguero, M. A. \& Kriwet, J. Eocene squalomorph sharks (Chondrichthyes, Elasmobranchii) from Antarctica. J. S. Am. Earth Sci. 78, 175-189 (2017).

19. Engelbrecht, A., Mörs, T., Reguero, M. A. \& Kriwet, J. New carcharhiniform sharks (Chondrichthyes, Elasmobranchii) from the early to middle Eocene of Seymour Island, Antarctic Peninsula. J. Vertebr. Paleontol. 10, e1371724 (2017).

20. Engelbrecht, A., Mörs, T., Reguero, M. A. \& Kriwet, J. Revision of Eocene Antarctic carpet sharks (Elasmobranchii, Orectolobiformes) from Seymour Island, Antarctic Peninsula. J. Syst. Palaeontol. 15, 969-990 (2017).

21. Engelbrecht, A., Mörs, T., Reguero, M. A. \& Kriwet, J. Skates and rays (Elasmobranchii, Batomorphii) from the Eocene La Meseta and Submeseta formations, Seymour Island, Antarctica. Hist. Biol. 10, 1-17 (2018).

22. Marramà, G., Engelbrecht, A., Mörs, T., Reguero, M. A. \& Kriwet, J. The southernmost occurrence of Brachycarcharias (Lamniformes, Odontaspididae) from the Eocene of Antarctica provides new information about the paleobiogeography and paleobiology of Paleogene sand tiger sharks. Riv. Ital. Paleontol. S. 124, 283-298 (2018).

23. Douglas, P. M. J. et al. Pronounced zonal heterogeneity in Eocene southern high-latitude sea surface temperatures. P. Natl Acad. Sci. USA 111, 6582-6587 (2014).

24. Amenábar, C. R., Montes, M., Nozal, F. \& Santillana, S. Dinoflagellate cysts of the La Meseta Formation (middle to late Eocene), Antarctic Peninsula: implications for biostratigraphy, palaeoceanography and palaeoenvironment. Geological Magazine, 1-16, https://doi.org/10.1017/S0016756819000591 (2019).

25. Fischer, G. Zoognosia. Tabulis Synopticis Illustrata, in Usum Prolectionum Academice Imperialis Medico-Chirurgica Mosquensis Edita 1-465 (Typis Nicolai Sergeidis Vsevolozsky, 1813).

26. Reig, O. A. Proposiciones para una nueva macrosistemática de los anuros (nota preliminar). Physis 21, 231-297 (1958).

27. Frost, D. R. et al. The amphibian tree of life. B. Am. Mus. Nat. Hist. 297, 1-370 (2006).

28. Reig, O. A. Las relaciones genéricas del anuro chileno Calyptocephalella gayi (Dum. and Bibr.). Actas y Trabajos I. Congreso Sudamericano Zoología, La Plata 1, 271-278 (1960).

29. Strand, E. Miscellanea nomenclatorica zoologica et paleontologica I-II. Arch. Naturgesch. 92, 30-75 (1928).

30. Gardner, J. D. et al. Comparative morphology of the ilium of anurans and urodeles (Lissamphibia) and a re-assessment of the anuran affinities of Nezpercius dodsoni Blob et al., 2001. J. Vertebr. Paleontol. 30, 1684-1696 (2010).

31. Bailon, S. Différenciation ostéologique des Anoures (Amphibia, Anura) de France 1-41 (Centre de Recherches Archéologiques du CNRS, 1999).

32. Rage, J.-C. Frogs (Amphibia, Anura) from the Eocene and Oligocene of the phosphorites du Quercy (France). An overview. Foss. Imprint 72, 53-66 (2016).

33. Folie, A. et al. Early Eocene frogs from Vastan Lignite Mine, Gujarat, India. Acta Palaeontol. Pol. 58, 511-524 (2013).

34. Clarac, F., Buffrénil, V., de, Brochu, C. \& Cubo, J. The evolution of bone ornamentation in Pseudosuchia: morphological constraints versus ecological adaptation. Biol. J. Linn. Soc. 121, 395-408 (2017).

35. Scheyer, T. M., Sander, P. M., Joyce, W. G., Böhme, W. \& Witzel, U. A plywood structure in the shell of fossil and living soft-shelled turtles (Trionychidae) and its evolutionary implications. Org. Divers. Evol. 7, 136-144 (2007).

36. Gardner, J. D., Evans, S. E. \& Sigogneau-Russell, D. New albanerpetontid amphibians from the Early Cretaceous of Morocco and Middle Jurassic of England. Acta Palaeontol. Pol. 48, 301-319 (2003).

37. Gardner, J. D. Albanerpetontid amphibians from the Upper Cretaceous (Campanian and Maastrichtian) of North America. Geodiversitas 22, 349-388 (2000).

38. Gardner, J. D. \& Rage, J.-C. The fossil record of lissamphibians from Africa, Madagascar, and the Arabian Plate. Palaeobio. Palaeoenv. 96, 169-220 (2016).

39. Estes, R. Gymnophiona, Caudata 1-115 (Gustav Fischer, 1981).

40. Schoch, R., Poschmann, M. \& Kupfer, A. The salamandrid Chelotriton paradoxus from Enspel and Randeck Maars (Oligocene-Miocene, Germany). Palaeobio. Palaeoenv. 95, 77-86 (2015).

41. Vickaryous, M. K. \& Hall, B. K. Development of the dermal skeleton in Alligator mississippiensis (Archosauria, Crocodylia) with comments on the homology of osteoderms. J. Morphol. 269, 398-422 (2008).

42. Alibardi, L. \& Thompson, M. B. Scale morphogenesis and ultrastructure of dermis during embryonic development in the alligator (Alligator mississippiensis, Crocodilia, Reptilia). Acta Zool. 81, 325-338 (2000). 
43. Buffrénil, Vde Morphogenesis of bone ornamentation in extant and extinct crocodilians. Zoomorphology 99, 155-166 (1982).

44. Estes, R. Sauria terrestria, Amphisbaenia 1-249 (Gustav Fischer, 1983).

45. Čerňanský, A. \& Augé, M. L. New species of the genus Plesiolacerta (Squamata: Lacertidae) from the upper Oligocene (MP28) of Southern Germany and a revision of the type species Plesiolacerta lydekkeri. Palaeontology 56, 79-94 (2013).

46. Cicimurri, D. J., Knight, J. L., Self-Trail, J. M. \& Ebersole, S. M. Late Paleocene glyptosaur (Reptilia: Anguidae) osteoderms from South Carolina, USA. J. Paleontol. 90, 147-153 (2016).

47. Vasilyan, D. Eocene Western European endemic genus Thaumastosaurus: New insights into the question "Are the Ranidae known prior to the Oligocene?". PeerJ 6, https://doi.org/10.7717/peerj.5511 (2018).

48. Gómez, R. O., Báez, A. M. \& Muzzopappa, P. A new helmeted frog (Anura: Calyptocephalellidae) from an Eocene subtropical lake in northwestern Patagonia, Argentina. J. Vertebr. Paleontol. 31, 50-59 (2011).

49. Báez, A. M. \& Gómez, R. O. Dealing with homoplasy: osteology and phylogenetic relationships of the bizarre neobatrachian frog Baurubatrachus pricei from the Upper Cretaceous of Brazil. J. Syst. Palaeontol. 16, 279-308 (2018).

50. Evans, S. E., Groenke, J. R., Jones, M. E. H., Turner, A. H. \& Krause, D. W. New material of Beelzebufo, a hyperossified frog (Amphibia: Anura) from the Late Cretaceous of Madagascar. Plos One 9, e87236, https://doi.org/10.1371/journal.pone.0087236 (2014).

51. Schaeffer, B. Anurans from the early Tertiary of Patagonia. B. Am. Mus. Nat. Hist. 93, 41-68 (1949).

52. Báez, A.M. The Late Cretaceous Fauna of Los Alamitos, Patagonia, Argentina (ed. Bonaparte J. F.) 121-130 (Museo Argentino de Sciencias Naturales Bernadino Rivadavia, 1987).

53. Otero, R. A., Jimenez-Huidobro, P., Soto-Acuña, S. \& Yury-Yáñez, R. E. Evidence of a giant helmeted frog (Australobatrachia, Calyptocephalellidae) from Eocene levels of the Magallanes Basin, southernmost Chile. J. S. Am. Earth Sci. 55, 133-140 (2014).

54. Vitt, L. J. \& Caldwell, J. P. Herpetology. An introductory biology of amphibians and reptiles 1-776 (Elsevier Academic Press, Amsterdam, 2013).

55. Veloso, A., Formas, R.J. \& Gerson, H. Calyptocephalella gayi. The IUCN Red List of Threatened Species (2010).

56. Cei, J. M. Batracios de Chile 1-128 (Universidad de Chile, Santiago, 1962).

57. Nicoli, L., Muzzopappa, P. \& Faivovich, J. The taxonomic placement of the Miocene Patagonian frog Wawelia gerholdi (Amphibia: Anura). Alcheringa 40, 153-160, https://doi.org/10.1080/03115518.2016.1101998 (2016).

58. Tyler, M. J. \& Godthelp, H. A new species of Lechriodus Boulenger (Anura: Leptodactylidae) from the Early Eocene of Queensland. T. Roy. Soc. South Aust. 117, 187-189 (1993).

59. Feng, Y.-J. et al. Phylogenomics reveals rapid, simultaneous diversification of three major clades of Gondwanan frogs at the Cretaceous-Paleogene boundary. P. Natl Acad. Sci. USA 114, E5864-E5870 (2017).

60. Vizcaíno, S.F., Kay, R.F. \& Bargo, M.S. (eds.). Early Miocene paleobiology in Patagonia: High-latitude paleocommunities of the Santa Cruz Formation 1-378 (Cambridge Univ. Press, 2012).

61. Francis, J.E. et al. Antarctica: A keystone in a changing world; proceedings of the $10^{\text {th }}$ International Symposium on Antarctic Earth Sciences, Santa Barbara, California (ed. Cooper, A. K. \& Barrett, P.) 19-27 (National Academies Press, 2008).

62. Nowak, R.M. \& Dickman, C.R. Walker's marsupials of the world 1-226 (Johns Hopkins University Press, 2005).

63. Nilsson, M. A. et al. Tracking marsupial evolution using archaic genomic retroposon insertions. Plos biology 8, e1000436, https://doi. org/10.1371/journal.pbio.1000436 (2010).

64. Goin, F. et al. New marsupial (Mammalia) from the Eocene of Antarctica, and the origins and affinities of the Microbiotheria. Rev. Asoc. Paleontol. Argentina 64, 597-603 (2007).

65. Unknown. Morphosource. Available at, https://www.morphosource.org/ (2020).

66. Gómez, R. O. \& Turazzini, G. F. An overview of the ilium of anurans (Lissamphibia, Salientia), with a critical appraisal of the terminology and primary homology of main ilial features. J. Vertebr. Paleontol. 36, e1030023 (2016).

67. The world bank groups. Climate Change Knowledge Portal (2017).

\section{Acknowledgements}

We thank the Argentine Antarctic Institute (IAA-DNA), the Argentine Air Force and the Swedish Polar Research Secretariat (SPFS) for logistical support in Antarctica; M. de los Reyes for screening and picking; E. M. Friis, S. McLoughlin and P. von Knorring for assistance with the figures; C. Mays and the late J.-C. Rage for helpful comments on an earlier manuscript version; handling editor C. Ohneiser, reviewer T. Worthy and an anonymous reviewer for their careful work which improved the manuscript significantly. This work was funded by the Swedish Research Council (VR grant number 2009-4447) to T.M., the Bolin Center for Climate Research, Stockholm University (RA6 grant) to T.M., the Consejo Nacional de lnvestigaciones Cientificas y Tecnicas (CONICET grant number PIP 0462) to M.R., and the Argentinian National Agency for Promotion of Science and Technology (ANPCyT grant number PICTO 0093/2010) to M.R.

\section{Author contributions}

T.M. and M.R. collected and processed the material. D.V. and T.M. analyzed the material. D.V. photographed the material, performed 3D reconstructions and provided the climate data. All authors discussed the results, wrote the manuscript and provided illustrations.

\section{Competing interests}

The authors declare no competing interests.

\section{Additional information}

Supplementary information is available for this paper at https://doi.org/10.1038/s41598-020-61973-5.

Correspondence and requests for materials should be addressed to T.M.

Reprints and permissions information is available at www.nature.com/reprints.

Publisher's note Springer Nature remains neutral with regard to jurisdictional claims in published maps and institutional affiliations. 
(c) (i) Open Access This article is licensed under a Creative Commons Attribution 4.0 International License, which permits use, sharing, adaptation, distribution and reproduction in any medium or format, as long as you give appropriate credit to the original author(s) and the source, provide a link to the Creative Commons license, and indicate if changes were made. The images or other third party material in this article are included in the article's Creative Commons license, unless indicated otherwise in a credit line to the material. If material is not included in the article's Creative Commons license and your intended use is not permitted by statutory regulation or exceeds the permitted use, you will need to obtain permission directly from the copyright holder. To view a copy of this license, visit http://creativecommons.org/licenses/by/4.0/.

(C) The Author(s) 2020 